\title{
ANALISIS KERAGAAN PERTUMBUHAN BENIH KERAPU HIBRIDA HASIL HIBRIDISASI KERAPU MACAN (Epinephelus fuscoguttatus) DENGAN KERAPU KERTANG (Epinephelus lanceolatus) DAN KERAPU BATIK (Epinephelus microdon)
}

\author{
Tatam Sutarmat dan Hirmawan Tirta Yudha \\ Balai Besar Penelitian dan Pengembangan Budidaya Laut \\ JI. Br. Gondol Kec. Gerokgak Kab. Buleleng, Kotak Pos 140, Singaraja, Bali 81101 \\ E-mail: info.gondol@gmail.com
}

(Naskah diterima: 8 Juli 2013; Disetujui publikasi: 2 Desember 2013)

\begin{abstract}
ABSTRAK
Analisis keragaan pertumbuhan benih ikan kerapu terdiri atas panjang, bobot, laju dan koefisien pertumbuhan, sintasan, dan faktor kondisi; merupakan aspek biologi yang penting diketahui dari kandidat ikan budidaya. Penelitian ini bertujuan untuk mengetahui hubungan panjang bobot, pertumbuhan, sintasan, konversi pakan, serta faktor kondisi benih ikan kerapu hibrida hasil hibridisasi kerapu macan (Epinephelus fuscoguttatus) dengan kerapu kertang dan kerapu batik (Epinephelus microdon). Benih hibrida yang digunakan terdiri atas kerapu hibrida cantang (kerapu macan $+x$ kerapu kertang $\delta^{\star}$ ), kerapu hibrida cantik (kerapu macan $+x$ kerapu batik $\delta$ ), serta kerapu macan (kerapu macan $+\mathrm{x}$ kerapu macan $\widehat{\alpha}$ ) sebagai kontrol. Dengan ukuran panjang dan bobot awal masing- masing antara $10-12 \mathrm{~cm}$ dan 22- $35 \mathrm{~g} /$ ekor. Benih dipelihara dalam sembilan buah jaring ukuran $2 \mathrm{~m} \times 2 \mathrm{~m} \times 2 \mathrm{~m}$ di keramba jaring apung (KJA) dengan padat penebaran benih uji sebanyak 250 ekor/jaring. Hasil akhir penelitian menunjukkan bahwa terdapat korelasi positif antara panjang dengan bobot pada kerapu hibrida cantang, cantik maupun kerapu macan dengan nilai koefisien korelasi masing-masing adalah 0,$933 ; 0,884$; dan 0,787 . Pertumbuhan dari ketiga benih ikan kerapu bersifat allometri negatif, dengan nilai b 2,533; 2,896; dan 2,546. Pada kerapu hibrida cantang, laju pertumbuhan dan koefisien pertumbuhannya lebih besar dibandingkan dengan benih kerapu yang lainnya. Hasil perkawinan silang juga berpengaruh sangat nyata terhadap konversi pakan, serta sintasan ikan yang dihasilkan. Faktor kondisi ikan kerapu hibrida cantang adalah 2,80; sedangkan pada kerapu hibrid cantik dan kerapu macan masing- masing adalah 2,12 dan 2,10.
\end{abstract}

KATA KUNCI: pertumbuhan, panjang, bobot, faktor kondisi, kerapu hibrida, kerapu macan

ABSTRACT: Performance analysis of seed grouper hybrid of cross breeding between tiger grouper Epinephelus fuscoguttatus with giant grouper Epinephelus lanceolatus and camouflage grouper (Epinephelus microdon). By: Tatam Sutarmat and Hirmawan Tirta Yudha

Performance analysis of seed grouper consisting of length, weight, growth rate, survival rate, and condition factor are important biological aspects for culture fish candidate. This experiment was aimed to get information regarding length-weight relationship, growth, and condition factor of seed grouper hybrid between tiger grouper Epinephelus fuscoguttatus with giant grouper Epinephelus lanceolatus and camouflage grouper 
(Epinephelus microdon). Hybrid seed consisted of cantang grouper (tiger grouper $x$ giant grouper $\delta^{\star}$ ), grouper hybrid cantik (tiger grouper $\$ x$ camouflage grouper $\delta$ ), and grouper tiger as control. It has 10-12 cm of length average and 22-35 g of weight average. The seed was reared in floating net cage $2 \mathrm{~m} \times 2 \mathrm{~m} \times 2 \mathrm{~m}$ with density of seed $250 \mathrm{fish} / \mathrm{cage}$. The results indicated that there was a positive length weight relationship between grouper hydrid cantang, cantik, and tiger grouper with range of correlation value $0.933,0.884$, and 0.787 . Growth of grouper were negatively allometric with $b$ value of 2.533 and 2.896 for hybrid cantang and hybrid cantik, while for grouper tiger was 2.546. Grouper hybrid cantang had growth, relative growth rate, and coefficient higher than those of hybrid cantik and tiger grouper. The cross breeding influenced significantly on growth, food conversion ratio, and survival rate. Condition factor was 2.80 for grouper hybrid cantang, while for hybrid cantik was 2.12 and 2.10 for tiger grouper, respectively.

\section{KEYWORDS: growth, length, weight, condition factor, hybrid grouper, tiger grouper}

\section{PENDAHULUAN}

Ikan kerapu macan merupakan jenis ikan laut komersial yang mulai banyak dibudidayakan, baik untuk pembenihan maupun pembesaran karena menjanjikan prospek yang bagus. Ikan kerapu macan (Epinephelus fuscoguttatus) merupakan jenis ikan laut komersial yang mulai banyak dibudidayakan, baik untuk pembenihan maupun pembesarannya karena menjanjikan prospek yang bagus (Sutarmat, 2005) dan merupakan jenis yang paling banyak diminati untuk budidaya karena pertumbuhannya cepat dibandingkan dengan jenis kerapu lainnya (Sutarmat et al., 2003). Kerapu kertang juga mempunyai prospek yang sangat bagus karena pertumbuhannya lebih cepat daripada kerapu macan, namun benihnya saat ini masih belum diproduksi secara massal (Puja \& Panudyamanu, 2007). Kerapu batik menjadi komoditas unggulan karena mudah beradaptasi, mempunyai nilai ekonomis tinggi dibandingkan kerapu macan dan relatif tahan terhadap penyakit, disukai konsumen namun lebih lambat tumbuh.

Permasalahan umum dalam budidaya ikan adalah bagaimana mendapatkan benih ikan yang tumbuh cepat, FCR rendah, tahan terhadap berbagai kondisi lingkungan dan penyakit, serta mempunyai morfologi yang disukai konsumen. Dalam rangka penyediaan ikan benih kerapu yang berkualitas dan berproduksi tinggi perlu dilakukan perbaikan pertumbuhan ikan kerapu melalui persilangan dari ikan yang potensial untuk budidaya dan dibutuhkan oleh masyarakat.

Hibridisasi merupakan perkawinan silang antar organisme yang berbeda secara gene- tik, baik dalam satu spesies (hibridisasi intraspesifik) maupun antar spesies (hibridisasi interspesifik). Hibridisasi telah menjadi cara yang efektif untuk mendapatkan karakteristik yang diinginkan atau meningkatkan kualitas ikan yang dibudidayakan. Hibridisasi dalam akuakultur bertujuan untuk mendapatkan ikan yang memiliki keunggulan dibandingkan kedua indukannya atau kombinasi keunggulan di antara keduanya, seperti memiliki laju pertumbuhan yang cepat, tahan terhadap serangan penyakit, memiliki toleransi terhadap perubahan lingkungan, meningkatkan kualitas daging ikan, dan sifat-sifat unggul lainnya. Hibridisasi dapat pula digunakan untuk memanipulasi rasio jenis kelamin dan juga memproduksi ikan yang bersifat steril (Bartley et al., 2001).

Penelitian tentang perkembangan benih kerapu hibrida hasil hibridisasi antara jantan kerapu kertang (Epinephelus Ianceolatus) dengan betina kerapu macan telah dilakukan di Balai Besar Penelitian dan Pengembangan Perikanan Budidaya Laut, Gondol. Larva kerapu hibrida mempunyai pertumbuhan lebih cepat dibandingkan dengan kerapu macan, pada kerapu hibrida umur 90 hari mempunyai ratarata panjang $12 \mathrm{~cm}$, sedangkan rata- rata panjang kerapu macan mencapai sekitar $7 \mathrm{~cm}$ (Ismi \&Yasmina, 2011)

Pada penelitian ini digunakan benih hibrida hasil perkawinan silang antara ikan kerapu macan sebagai induk betina dengan kerapu kertang dan kerapu batik (Epinephelus microdon) sebagai induk jantan. Keragaan pertumbuhan benih hibrida merupakan gambaran karakter tumbuh yang dapat diukur dari suatu individu. 
Untuk mendapatkan model usaha budidaya dengan ciri- ciri sebagaimana telah disebutkan di atas, perlu dipelajari terlebih dulu aspek biologi ikan tersebut, terutama yang menyangkut sifat pertumbuhan dan faktor kondisi yang memengaruhinya. Hasil analisis hubungan antara panjang dan bobot ikan tersebut secara matematis, diharapkan dapat diketahui kecepatan pertumbuhan, kondisi biologis berupa kapasitas reproduksi, dan kemampuan memproduksi daging ikan yang berkualitas secara komersial (Royce, 1984).

Penelitian ini bertujuan untuk menganalisis keragaan pertumbuhan benih hibrida yang terdiri atas hubungan panjang bobot, laju, dan koefisien pertumbuhan, sintasan konversi pakan, serta faktor kondisi.

\section{BAHAN DAN METODE}

Penelitian dilakukan di keramba jaring apung (KJA) Balai Besar Penelitian dan Pengembangan Budidaya Laut, Gondol, Bali. Ikan uji yang digunakan kerapu hibrida cantang (kerapu macan +9 kerapu kertang ${ }^{*}$ ), kerapu hibrida cantik (kerapu macan $9 \mathrm{x}$ kerapu batik $\delta$ ), serta kerapu macan (kerapu macan $+x$ kerapu macan ơ) sebagai kontrol. Benih berasal hasil pembenihan dari Balai Besar Penelitian dan Pengembangan Budidaya Laut, Gondol, Bali.

Pengujian pertumbuhan dilakukan di KJA Teluk Pegametan Bali dengan menggunakan sembilan buah jaring $2 \mathrm{~m} \times 2 \mathrm{~m} \times 2 \mathrm{~m}$. Padat penebaran benih uji sebanyak 250 ekor/jaring dengan ukuran panjang dan bobot awal masing- masing antara $10-12 \mathrm{~cm}$ dan $22-35 \mathrm{~g} /$ ekor. Selama pemeliharaan ikan diberi pakan berupa pelet komersial yang ukurannya disesuaikan dengan ukuran ikan.

Berdasarkan hasil analisis proksimat (persentase bahan kering), pakan buatan yang diberikan mengandung komposisi sebagai berikut: protein 54,91\% lemak 14,30\% dan abu $11,32 \%$ Pemberian pakan dilakukan sampai kenyang (ad libitum) dengan frekuensi pemberian pakan 2- 3 kali/ hari.

Pengukuran terhadap panjang dan bobot individu dilakukan setiap bulan sekali selama tiga bulan dengan cara pengambilan ikan sebanyak 30 ekor untuk setiap ulangan.

Analisis hubungan panjang- bobot, kecepatan pertumbuhan, dan koefisien pertumbuhan dilakukan mengacu pada rumus matematis menurut Effendie (2002), sedangkan untuk analisis faktor kondisi mengacu pada Royce (1984). Hubungan panjang bobot dinyatakan dengan rumus:

$$
\mathrm{W}=\mathrm{aL}^{\mathrm{b}}
$$

di mana:

$\mathrm{W}=$ Bobot

$\mathrm{L}=$ Panjang

$\mathrm{a}$ dan $\mathrm{b}=$ Konstanta

Kecepatan pertumbuhan dinyatakan dengan rumus:

$$
\mathrm{GR}=(\mathrm{Wt}-\mathrm{Wo}) / \mathrm{t}
$$

di mana:

$\mathrm{GR}=$ Laju pertumbuhan

Wt $=$ Bobot pada waktu $\mathrm{t}$

Wo $=$ Bobot pada waktu awal

$\mathrm{t}=$ Lama pemeliharaan

Koefisien pertumbuhan dinyatakan dengan rumus:

$$
\mathrm{Gt}=\ln (\mathrm{Wt} / \mathrm{Wo})
$$

di mana:

Gt $=$ Koefisien pertumbuhan

Wt $=$ Bobot pada waktu $\mathrm{t}$

Wo $=$ Bobot pada waktu awal

Faktor kondisi dinyatakan sebagai:

$$
W / 100 L^{3}
$$

di mana:

$\mathrm{W}=$ Bobot

$\mathrm{L}=$ Panjang

Rancangan percobaan yang digunakan adalah rancangan acak lengkap (RAL), dengan menggunakan tiga perlakuan jenis ikan kerapu dengan tiga ulangan. Analisis data dilakukan dengan menggunakan ANOVA untuk mengetahui tingkat perbedaan yang ada.

\section{HASIL DAN BAHASAN}

\section{Pertumbuhan Panjang dan Bobot}

Berdasarkan hasil pengamatan, rataan kecepatan, dan koefisien pertumbuhan panjang tertinggi diperoleh pada ikan kerapu cantang, sedang terendah pada ikan kerapu cantik (Tabel 1).

Analisis statistik terhadap kecepatan dan koefisien pertumbuhan ukuran panjang ketiga jenis kerapu memperlihatkan bahwa ikan 
Tabel 1. Panjang awal dan akhir, kecepatan dan koefisien pertumbuhan kerapu hibrid cantang, cantik, dan kerapu macan $(n=30)$

Table 1. Initial and final lenght, growth rate, and growth coefficient of hybrid grouper cantang, cantik, and tiger grouper $(n=30)$

\begin{tabular}{|c|c|c|c|c|}
\hline \multirow{2}{*}{$\begin{array}{l}\text { Kerapu } \\
\text { Grouper }\end{array}$} & \multicolumn{2}{|c|}{ Panjang (Length) (cm) } & \multirow{2}{*}{$\begin{array}{c}\text { Kecepatan } \\
\text { pertumbuhan } \\
\text { Growth rate (\%) }\end{array}$} & \multirow{2}{*}{$\begin{array}{c}\text { Koefisien } \\
\text { pertumbuhan } \\
\text { Growth coefficient }\end{array}$} \\
\hline & 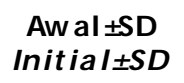 & $\begin{array}{l}\text { Akhir } \pm \text { SD } \\
\text { Final } \pm \text { SD }\end{array}$ & & \\
\hline Cantang & $9.49 \pm 1.09$ & $19.02 \pm 1.62$ & $95 \pm 8^{b}$ & $0.67 \pm 0.05^{b}$ \\
\hline Cantik & $10.10 \pm 0.57$ & $15.67 \pm 1.09$ & $54 \pm 7^{a}$ & $0.43 \pm 0.04^{a}$ \\
\hline Macan & $10.49 \pm 1.19$ & $16.62 \pm 1.12$ & $59 \pm 6^{a}$ & $0.46 \pm 0.06^{a}$ \\
\hline
\end{tabular}

Keterangan (Note):

Nilai dalam kolom diikuti huruf yang sama menunjukkan tidak berbeda nyata $(P>0,005)$ (Value within the column with the same letter are not significantly different $(P>0.05))$

kerapu cantang nyata lebih tinggi $(P>0,05)$ dibandingkan dengan ikan kerapu cantik dan macan $(P>0,05)$. Adanya perbedaan pertambahan panjang yang diperoleh, memberikan indikasi terjadinya perbedaan pertumbuhan secara morfometrik dari ikan kerapu yang diuji. Hal ini diduga berkaitan dengan keragaan genetik dari ikan kerapu hibrid cantang yang berbeda dengan ikan kerapu macan dan kerapu cantik. Berdasarkan pola pertambahan panjang per bulan menunjukkan pertambahan panjang ikan kerapu cantang lebih cepat dibandingkan pada ikan kerapu lainnya (Gambar 1).

Kecepatan pertumbuhan rata- rata pertambahan bobot tertinggi diperoleh pada ikan kerapu cantang, sedangkan yang terendah terdapat pada kerapu cantik (Tabel 2). Berdasarkan uji statistik memperlihatkan bahwa kecepatan pertumbuhan kerapu cantang nyata lebih tinggi dibandingkan kerapu cantik dan kerapu macan $(P>0,05)$. Namun antara kerapu cantik dan kerapu macan kecepatan tumbuh tidak memperlihatkan perbedaan $(P<0,05)$. Gambar 2 nampak pula bahwa pertumbuhan bobot ikan kerapu cantang lebih cepat dibandingkan pertumbuhan pada ikan kerapu cantik dan macan. Perbedaan ini jelas terlihat setelah 30 hari.

Kecepatan pertumbuhan bobot pada ikan kerapu cantang mencapai $714 \%$ sedangkan pertumbuhan yang sama pada kerapu cantik

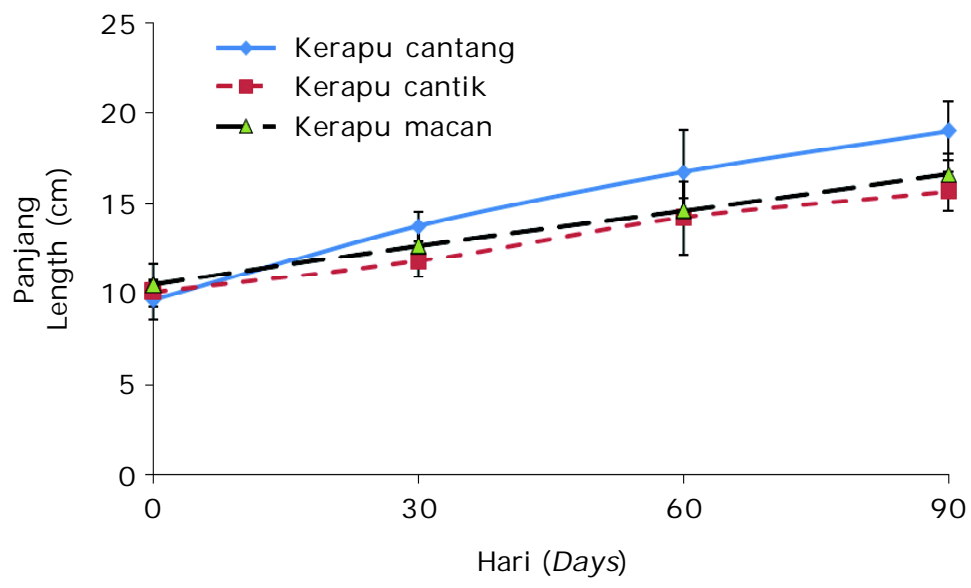

Gambar 1. Rata- rata pertambahan panjang tiga jenis kerapu selama 90 hari pemeliharaan

Figure 1. The average of length gain of three grouper obtained from 90 days observation 
Tabel 2. Kecepatan dan koefisien pertumbuhan bobot kerapu hibrid cantang, cantik, dan kerapu macan

Table 2. Growth rate and growth coefficient based on body weight of cantang, cantik grouper hybrid, and tiger grouper

\begin{tabular}{|c|c|c|c|c|}
\hline \multirow{2}{*}{$\begin{array}{l}\text { Kerapu } \\
\text { Grouper }\end{array}$} & \multicolumn{2}{|c|}{ Bobot (Weight ) (g) } & \multirow{2}{*}{$\begin{array}{c}\text { Kecepatan } \\
\text { pertumbuhan } \\
\text { Growth rate (\%) }\end{array}$} & \multirow{2}{*}{$\begin{array}{c}\text { Koefisien } \\
\text { pert umbuhan } \\
\text { Growth coefficient }\end{array}$} \\
\hline & 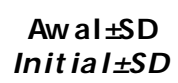 & $\begin{array}{l}\text { Akhir } \pm \text { SD } \\
\text { Final } \pm \text { SD }\end{array}$ & & \\
\hline Cantang & $24.1 \pm 7.8$ & $195 \pm 44$ & $714 \pm 111^{b}$ & $2.09 \pm 0.13^{b}$ \\
\hline Cantik & $23.5 \pm 3.9$ & $83 \pm 18$ & $261+24^{a}$ & $1.24 \pm 0.12^{\mathrm{a}}$ \\
\hline Macan & $24.7 \pm 8.0$ & $97 \pm 18$ & $295 \pm 32^{a}$ & $1.37 \pm 0.08^{\mathrm{a}}$ \\
\hline
\end{tabular}

Keterangan (Note):

Nilai dalam kolom diikuti huruf yang sama menunjukkan tidak berbeda nyata $(P>0,005)$ (Value within the column with the same letter are not significantly different $(P>0.05))$

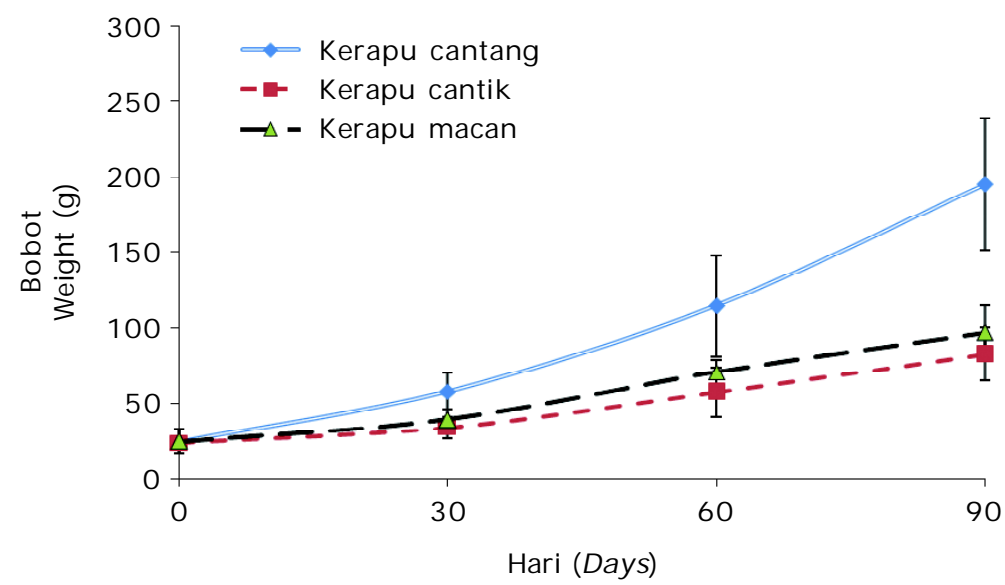

Gambar 2. Rata- rata pertambahan bobot tiga jenis kerapu selama 90 hari pemeliharaan

Figure 2. The average of weight gain of three grouper obtained from 90 days observation

dan macan masing- masing adalah $261 \%$ dan $295 \%$ Hasil analisis ragam terhadap kecepatan pertumbuhan ikan kerapu cantang menunjukkan bahwa perlakuan perkawinan silang memberikan pengaruh sangat nyata terhadap kecepatan pertumbuhan bobot $(P>0,05)$.

Kondisi ini diduga karena kerapu cantang hasil hibridisasi mewarisi gen pertumbuhan dari kerapu kertang yang relatif tinggi, juga mempunyai nafsu makan yang tinggi, serta dapat memanfaatan pakan lebih baik untuk mengimbangi laju metabolismenya, dibandingkan dengan benih dari perkawinan silang lainnya. Kerapu cantik memiliki pertumbuhan yang paling rendah, hal ini diduga bahwa benih kerapu hasil perkawinan silang antara kerapu batik jantan dengan ikan kerapu macan betina mewarisi sifat kerapu batik yang laju pertumbuhannya relatif lambat dan respons terhadap pakan kurang dibandingkan kerapu lainnya.

Hasil penelitian memperlihatkan pula bahwa koefisien pertumbuhan tertinggi pada kerapu cantang $(2,09)$ dan terendah pada kerapu cantik $(1,24)$ yang tersaji pada Tabel 2 . Analisis koefisien pertumbuhan bobot menunjukkan bahwa perkawinan silang memberikan pengaruh sangat nyata lebih tinggi $(P<0,01)$ pada benih hasil perkawinan silang 
antara kerapu kertang jantan dengan ikan kerapu macan betina. Berdasarkan uji Duncan diketahui bahwa koefisien pertumbuhan antara kerapu cantik dan macan tidak berbeda nyata $(P<0,05)$. Pada penelitian ini, ikan kerapu hibrid cantang dapat memanfaatkan pakan dengan baik sehingga pertumbuhannya lebih cepat. Rutten et al. (2005), juga menyatakan bahwa untuk mendapatkan pertumbuhan yang relatif cepat bergantung dari kemampuan ikan tersebut untuk memanfaatkan secara maksimal pakan yang diberikan.

\section{Sintasan}

Hasil penelitian sintasan tertinggi terdapat pada kerapu cantik (93,3\%) diikuti kerapu cantang $(84,9 \%)$ dan terendah pada kerapu macan $(81,3 \%$. Seperti monogram yang disajikan pada Gambar 3. Berdasarkan hasil uji statistik memperlihatkan bahwa sintasan kerapu cantik nyata lebih tinggi dibandingkan kerapu cantang dan kerapu macan $(P>0,05)$.

Keunggulan kerapu cantik hasil hibridisasi antara kerapu batik jantan dengan ikan kerapu macan betina memiliki tingkat sintasan yang tinggi karena bawaan genetik, benih memiliki materi genetik lebih baik sehingga memiliki ketahanan tubuh yang baik. Sedangkan pada kerapu cantang yaitu hasil persilangan silang antara kerapu kertang jantan dengan ikan kerapu macan betina memiliki persentase sintasan yang rendah. Hal tersebut diduga bahwa ada gen pengontrol kemampuan beradaptasi yang bersifat resesif yang oleh salah satu induknya diturunkan kepada benih hasil hibridisasi tersebut. Hibridisasi dapat menimbulkan heterozigositas yang menguatkan daya tahan individu terhadap lingkungan, sehingga dapat menghasilkan sintasan yang tinggi (Basuki \& Susilowati, 2009).

\section{Konversi Pakan}

Konversi pakan dapat menggambarkan tingkat efisiensi kemampuan individu maupun spesies ikan dalam memanfaatkan pakan. Pada akhir penelitian menunjukkan bahwa konversi pakan tertinggi pada ikan kerapu macan $(2,2 \pm 0,2)$ dan terendah pada ikan kerapu cantang $(1,4 \pm 0,2)$. Data mengenai konversi pakan selengkapnya tersaji dalam grafik pada Gambar 4. Berdasarkan analisis statistik diketahui bahwa perlakuan perkawinan silang memengaruhi sangat nyata $(P<0,01)$ terhadap konversi pakan. Hasil uji Duncan terhadap konversi pakan antara kerapu cantang, kerapu cantik, dan kerapu macan memperlihatkan perbedaan yang nyata $(P>0,05)$. Konversi pakan cantang nyata lebih rendah dibandingkan dengan kerapu cantik dan kerapu macan. Menurut Huet (1989), beberapa faktor yang dapat memengaruhi angka konversi pakan antara lain adalah kepadatan ikan, bobot setiap individu, tingkat umur ikan, status kesehatan ikan, kualitas air perairan, serta metode pemberian pakan. Hepher (1988) menyatakan bahwa konversi pakan akan bertambah secara bertahap seiring dengan bertambahnya bobot.

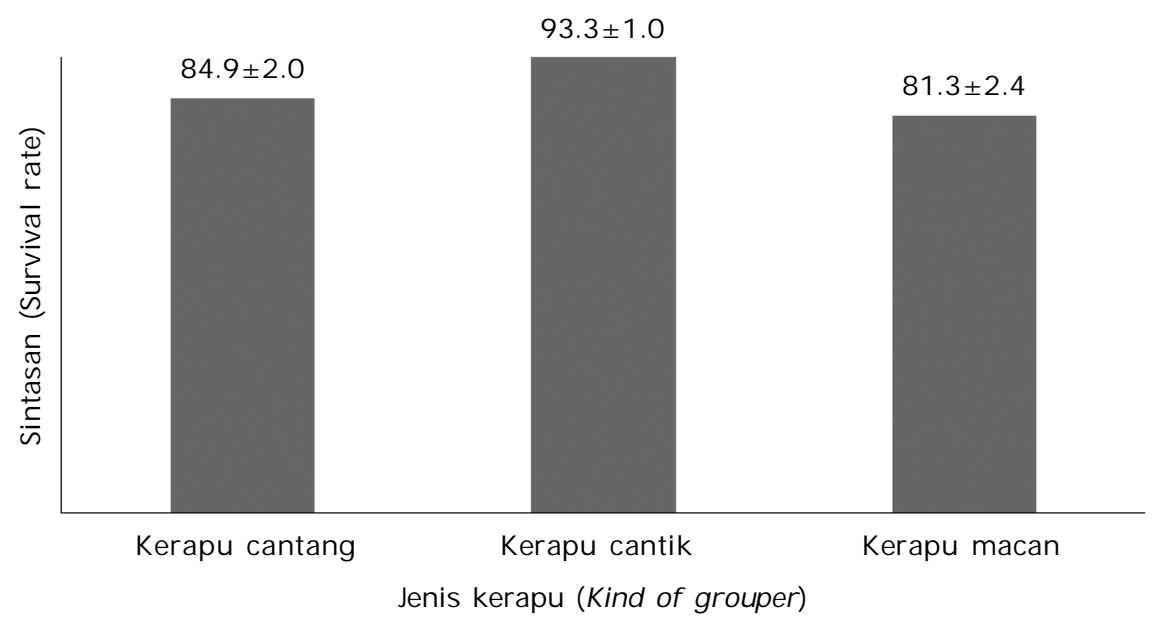

Gambar 3. Monogram sintasan kerapu cantang, kerapu cantik, dan kerapu macan

Figure3. Monogram survival rate of cantang, cantik, and tiger grouper 


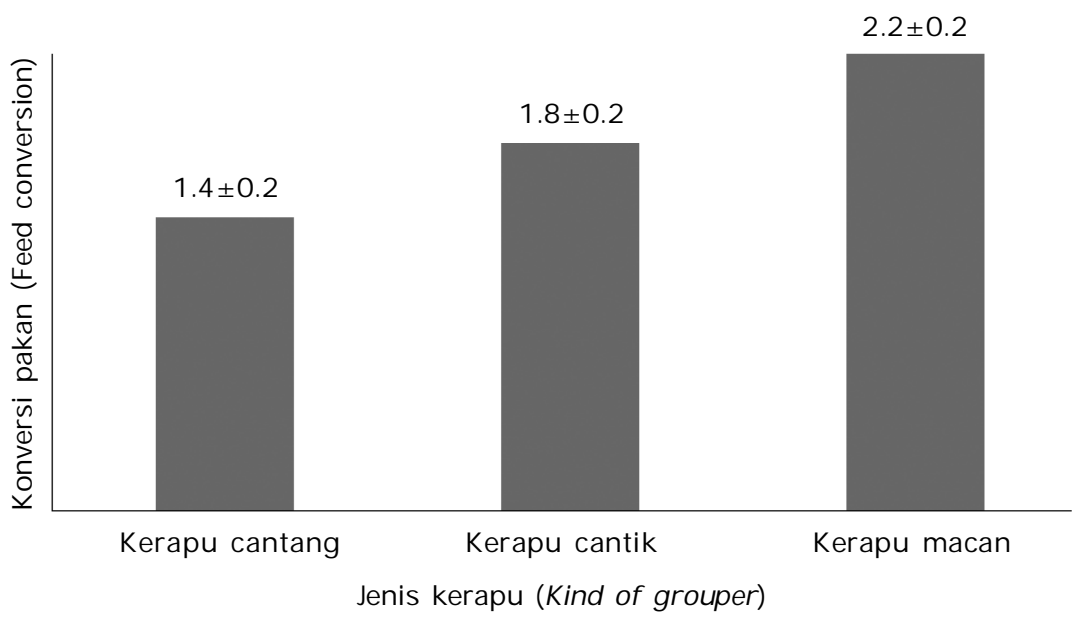

Gambar 4. Monogram konversi pakan kerapu cantang, kerapu cantik, dan kerapu macan

Figure 4. Monogram feed conversion of cantang, cantik and tiger grouper

\section{Analisis Hubungan Panjang dan Bobot}

Hubungan panjang dan bobot ikan kerapu hibrida cantang, cantik, dan kerapu macan pada awal penelitian pada dapat dilihat pada Gambar 5. Pada ikan kerapu hibrida cantang dan kerapu macan terlihat korelasi positif yang tinggi antara panjang dan bobot ikan dengan koefisien korelasi masing- masing sebesar 0,93 dan 0,91 . Nilai konstanta $b$ yang masingmasing hampir sama dengan 3 , yaitu 2,859 dan 2,924; hal ini menunjukkan bahwa bobot ikan uji yang digunakan pada awal penelitian mengikuti pertumbuhan panjangnya secara isometri. Sedangkan pada kelompok ikan kerapu hibrida cantik terlihat korelasi positif yang lebih rendah antara panjang dan bobot dengan nilai koefisien korelasi 0,849 . Nilai b pada kerapu hibrida cantik lebih rendah dibandingkan nilai kerapu yang lainnya yaitu 2,752 . Hal ini menunjukkan bahwa penambahan bobot yang mengikuti pertumbuhan panjang pada kerapu cantik lebih kecil dibandingkan dengan pertambahan bobot ikan kerapu hibrida cantang dan kerapu macan.

Pada akhir penelitian yakni setelah masa penelitian 90 hari kerapu hibrid cantang, cantik, dan kerapu macan dilakukan pula analisis hubungan panjang-bobot yang hasilnya sebagaimana terlihat pada Gambar 6.

Hasil analisis tersebut menunjukkan bahwa untuk kerapu cantang, baik nilai koefisien korelasi antara panjang dan bobot $(0,933)$ maupun nilai b $(2,533)$ tidak berbeda nyata dengan koefisien korelasi $(0,927)$ maupun nilai b $(2,859)$ pada masa awal pemeliharaan. Untuk kerapu cantik baik nilai koefisien korelasi antara panjang dan bobot $(0,844)$ maupun nilai b $(2,896)$ tidak berbeda nyata dengan koefisien korelasi $(0,849)$ maupun nilai $b(2,752)$ pada masa awal pemeliharaan. Sedangkan kerapu macan diperoleh hasil sedikit berbeda, baik nilai koefisien korelasi maupun nilai $b$, keduanya menurun di mana koefisien korelasi yang semula 0,910 menurun menjadi 0,787 ; sedang nilai b yang pada awal bernilai 2,924 menurun menjadi 2,546. Dengan nilai b yang lebih kecil dari 3, baik pada awal maupun akhir penelitian, menunjukkan bahwa ikan kerapu memiliki pertumbuhan yang allometrik, di mana pertumbuhan bobot ikan cenderung terjadi lebih cepat dibandingkan pertumbuhan panjangnya.

\section{Faktor Kondisi}

Faktor kondisi ikan kerapu cantang pada awal penelitian lebih tinggi, diikuti kerapu cantik dan terkecil pada kerapu macan, masingmasing yaitu $2,58 \pm 0,24 ; 2,27 \pm 0,16$; dan 2,07 $\pm 0,23$ (Tabel 3).

Pada akhir penelitian yakni setelah masa pemeliharaan 90 hari menunjukkan bahwa faktor kondisi ikan kerapu cantang cenderung lebih tinggi dibandingkan dengan awal penelitian yaitu $2,80 \pm 0,19$; tetapi pada ikan kerapu cantik cenderung faktor kondisi lebih 
J. Ris. Akuakultur Vol. 8 No. 3 Tahun 2013: 363-372

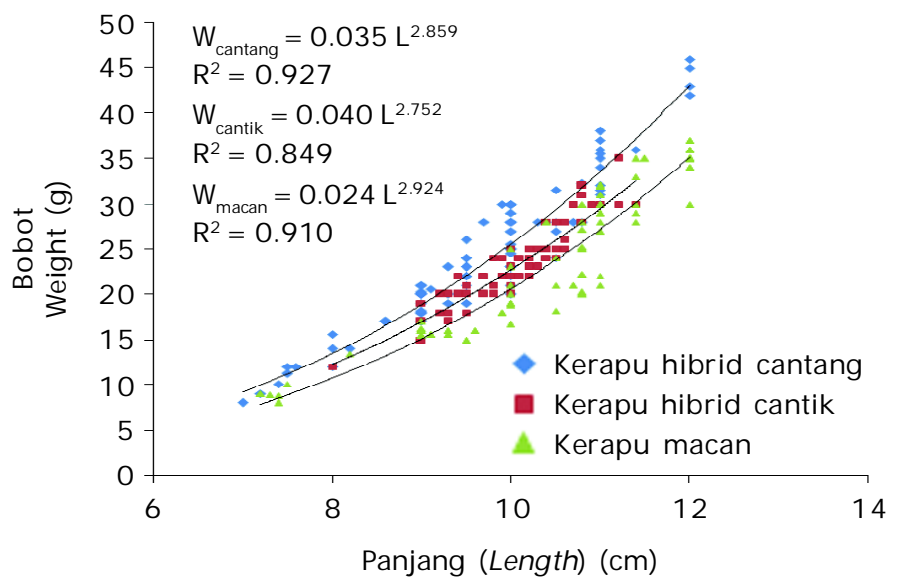

Gambar 5. Hubungan panjang-bobot ikan kerapu hibrid cantang, cantik, dan kerapu macan pada awal penelitian

Figure 5. Length-weight relationship of hybrid grouper cantang, cantik, and tiger grouper at the beginning of the experiment

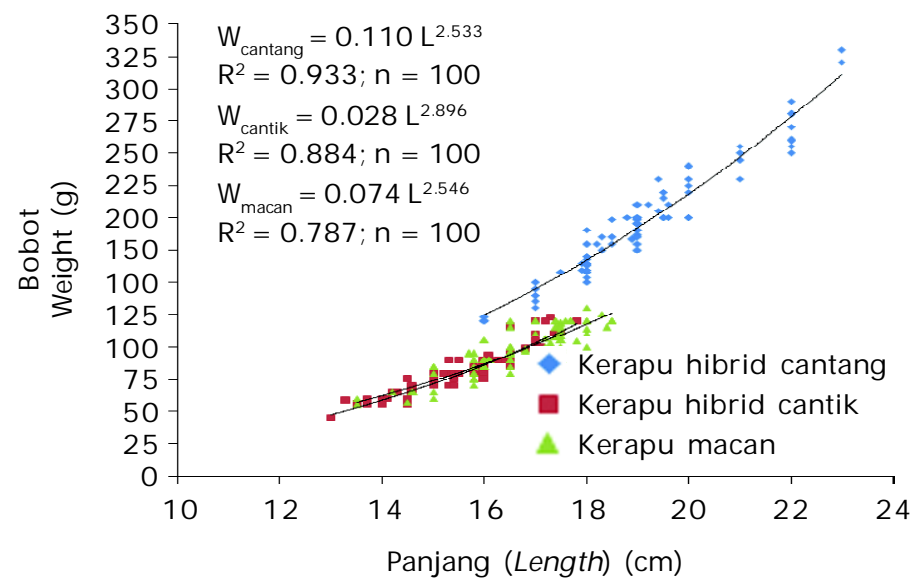

Gambar 6. Hubungan panjang-bobot ikan kerapu hybrid cantang, cantik dan kerapu macan pada akhir penelitian

Figure 6. Length-weight relationship of hybrid grouper cantang, cantik, and tiger grouper at the end of the experiment

rendah dibandingkan dengan pada awal penelitian yaitu $2,12 \pm 0,16$. Sedangkan pada kerapu macan pada awal penelitian faktor kondisi hampir sama yaitu 2,10 0,21 .

Dengan nilai faktor kondisi yang seperti itu nampak bahwa ikan kerapu cantang berada di atas dua yang artinya lebih gemuk. Dengan demikian kerapu hibrid cantang bentuk badan pipih dan relatif membulat dengan ukuran lebar kepala sedikit atau hampir sama dengan lebar badannya sedangkan pada kerapu cantik dan macan bentuk badan pipih sedikit memanjang (Gambar 7).

\section{KESIMPULAN}

- Pertumbuhan dan koefisien pertumbuhan pada ikan kerapu hibrida cantang adalah lebih besar daripada kerapu hibrida cantik dan kerapu macan

- Kerapu hibrida cantang, cantik maupun kerapu macan pada akhir penelitian mem- 
Tabel 3. Faktor kondisi ikan kerapu hibrid cantang, cantik, dan kerapu macan pada awal dan akhir penelitian

Table3. Condition factor of hybrid grouper cantang, cantik, and tiger grouper at the initial and final of the experiment

\begin{tabular}{lcc}
\hline $\begin{array}{c}\text { Jenis kerapu } \\
\text { Kind of grouper }\end{array}$ & $\begin{array}{c}\text { Awal } \\
\text { Initial }\end{array}$ & $\begin{array}{c}\text { Akhir } \\
\text { Final }\end{array}$ \\
\hline Kerapu cantang & $2.58 \pm 0.24$ & $2.80 \pm 0.19$ \\
Kerapu cantik & $2.27 \pm 0.16$ & $2.12 \pm 0.16$ \\
Kerapu macan & $2.07 \pm 0.23$ & $2.10 \pm 0.21$ \\
\hline
\end{tabular}

punyai nilai korelasi positif antara panjang dengan bobot masing-masing adalah 0,$933 ; 0,884$; dan 0,787

- Analisis hubungan panjang-bobot, pertumbuhan dari ketiga benih ikan kerapu bersifat allometri negatif, dengan nilai $b$ 2,533; 2,896; dan 2,546

- Faktor kondisi ikan kerapu hibrida cantang adalah 2,80; sedangkan pada kerapu hibrida cantik dan kerapu macan masingmasing adalah 2,12 dan 2,10. Dengan demikian kerapu hibrida cantang bentuk relatif membulat dengan ukuran lebar kepala sedikit atau hampir sama dengan lebar badannya sedangkan pada kerapu cantik dan macan bentuk badan sedikit membulat

\section{UCAPAN TERIMA KASIH}

Ucapan terima kasih kepada teknisi keramba jaring apung Balai Besar Penelitian dan Pengembangan Budidaya Laut atas peran sertanya dalam pemeliharaan ikan kerapu uji selama penelitian ini berlangsung.

\section{DAFTAR ACUAN}

Basuki, F. \& Susilowati, T. 2009. Analisis performa reproduksi induk dan benihnya hasil persilangan ikan nila GIFT (Oreochromis sp.) F- 2 dengan nila merah Singapura (Oreochromis sp.) F- 2. Aquacultura Indonesiana (MAl), 10(3): 141- 147.

Bartley, D.M., Rana, K., \&lmmink, A.J. 2001. The use of inter-specific hybrids in aquaculture and fisheries. Reviews in Fish Biology and Fisheries 10. Kluwer Academic Publishers. p. 325- 337 .
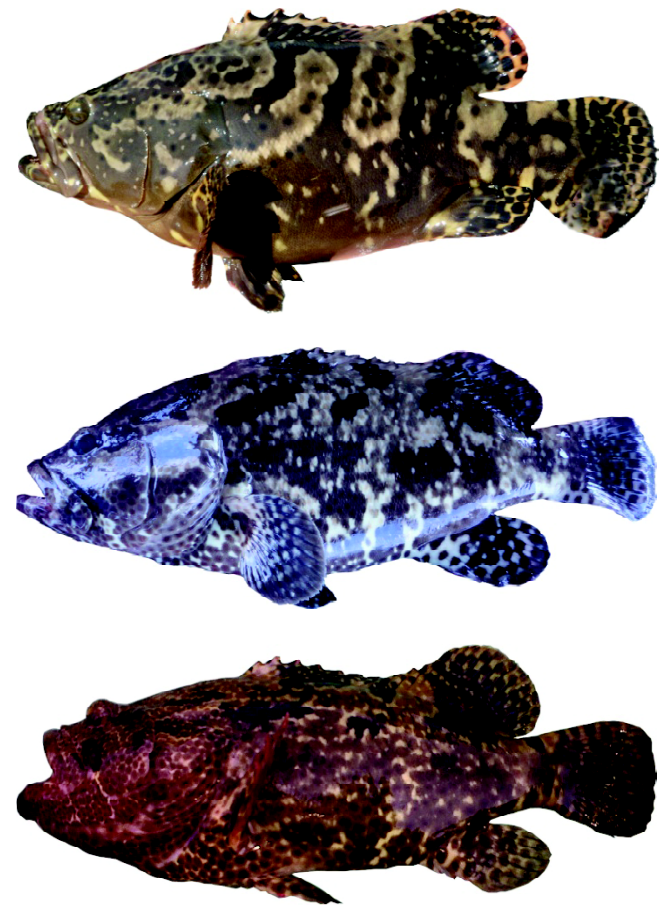

Gambar 7. Kerapu hibrida cantang, cantik, dan kerapu macan

Figure 7. Hybrid grouper cantang, cantik and tiger grouper

Effendie, M.I. 2002. Biologi perikanan. Yayasan Pustaka Nusantara. Yogyakarta, $163 \mathrm{hlm}$.

Hepher, B. 1988. Nutrition of pond fishes. Formerly of Fish and Aquaculture Research Station Dor Israel.Cambridge University Press. 388 pp.

Huet, M. 1989. Text book of fish culture. Breeding and Cultivation of Fish. Fishing News Book Ltd. Surrey. London, $354 \mathrm{pp}$.

Ismi, S. \& Yasmina, N.A. 2011. Pengamatan perkembangan benih kerapu hidrid hasil persilangan antara jantan kerapu kertang (Epinephelus lanceolatus) dengan betina kerapu macan (E. fuscoguttatus). Prosiding Seminar Nasional Kelautan VII. Inspiring Sea For Live: Tantangan dalam Pengelolaan Sumberdaya secara Bijaksana dan Berkelanjutan. Universitas Hang Tuah, Surabaya, 20 April 2011. hlm. 81- 100.

Puja, Y. \& Panudyamanu. 2007. Rekayasa teknologi pembesaran ikan kerapu kertang (Epinephelus lanceolatus) di KJA. Laporan Kegiatan Perekayasaan. Balai Besar 